\title{
An examination of Turkish physical education teachers' interpersonal self-efficacy beliefs
}

\author{
Öncü E. ${ }^{A B C D E}$ \\ Faculty of Sport Sciences, Department of Physical Education and Sport Teaching, Trabzon University, Trabzon, \\ Turkey
}

Authors' Contribution: A - Study design; B - Data collection; C - Statistical analysis; D - Manuscript Preparation; E - Funds Collection.

\begin{abstract}
Purpose: $\quad$ This study was conducted for two purposes. The first purpose was to examine the psychometric properties of the Teacher Interpersonal Self-Efficacy Scale (TISES) for Turkish Physical Education (PE) teachers and the second was to analyze teachers' interpersonal self-efficacy beliefs according to some demographic variables.

Material: $\quad$ The study was conducted on 360 Turkish PE teachers. Confirmatory factor analysis was applied in order to verify the factor structure of the scale. Pearson's product-moment coefficients were used in order to assess the correlations between the factors. For determining the reliability of the scale Cronbach Alpha coefficient was calculated. Multivariate analysis of variance was used to determine differences between the scores acquired from the scale and some independent variables.

Results: $\quad$ The results confirm the 3-factor internal structure of the TISES. The results of the correlation analysis between the TISES subscales indicated significant and positive relationships. We also found acceptable values of the alpha coefficient, which confirms the TISES as a reliable instrument. Overall, all physical education teachers had positive self-efficacy beliefs on high levels. Whereas by gender significant difference was not found in self-efficacy beliefs, significant difference were found between teachers depending on years of experience and grade levels they taught.

Conclusions: The reexamination of the scale led to a new scale structure comprised of three factors with sixteen items. The TISES is a relatively short questionnaire that allows researchers to measure interpersonal self-efficacy beliefs of PE teachers. The experienced teachers and the teachers who were employed at the high schools had higher self-efficacy belief levels.

Keywords: teacher efficacy, classroom management, scale development, validity, reliability.
\end{abstract}

\section{Introduction}

A key component of a teacher's beliefs and knowledge is self-efficacy [1] since a teacher's self-perception is one of the essential factors determining his/her competence in the profession. Perceived teacher efficacy has been defined as "the extent to which the teacher believes he or she has the capacity to affect student performance" [2, p. 137] or as "teachers' belief or conviction that they can influence how well students learn, even those (students) who may be difficult or unmotivated" [3]. In other words, a teacher's efficacy belief is a part of the active roleplaying process in which he/she arrives at "a judgment of his/her capabilities to bring about desired outcomes of student engagement and learning, even among those students who may be difficult or unmotivated" [4].

The importance of self-efficacy for teachers has been the subject of serious academic research that has approached the issue from many different aspects. According to Brouwers and Tomic [5], for example, teachers who believed that they are competent to teach their students were considered to have strong self-efficacy beliefs in teaching, whereas teachers who doubted their ability in this respect were considered to have weak self-efficacy beliefs in teaching. It can be argued that teachers who have high teacher self-efficacy beliefs are more capable of using instructional strategies effectively, more capable of ensuring student participation and more successful in (๑) Öncü E., 2019

doi:10.15561/20755279.2019.0106 classroom management skills [6, 7]) and they use direct teaching less [8]. Teachers with high teacher self-efficacy make more efforts to overcome the problems they face, and they can maintain these efforts longer $[9,10]$. Studies also demonstrate that differences exist between teachers with high and low self-efficacy beliefs in issues such as using new techniques and giving feedback to students with learning disabilities [4, 11]. Teacher self-efficacy belief (TSEB) also enables the teacher to be open to new ideas and to develop positive teaching attitudes [12, 13], and to take more responsibility in teaching [14].

Another argument is that perceived teaching selfsufficiency is positively associated with teachers' job satisfaction $[6,15]$. This was thoroughly presented in the study of Tschannen-Moran and Hoy [16], which showed that the satisfaction derived from classroom performance, is positively correlated with teaching self-efficacy belief. Klassen et al. also found a high correlation, in the study they carried out in five different countries, between teachers' job satisfaction levels and teaching self- efficacy beliefs. Exploring the relationship between TSEB and job satisfaction may have implications for teachers' job performance, and by extension, the academic achievement of students [17].

Other dimensions of self-efficacy extend beyond satisfaction, performance and academic achievement issues. Teacher self-efficacy is also positively related to perceptions of parental (e.g. home tutoring) involvement 
[18], administrative attention and support [8], colleague collaboration [19] and a rigorous academic climate [20]. Moreover, teacher efficacy has been linked to the content that teachers teach, the pedagogies they employ, and their perspectives on teaching diverse students $[21,22]$. According to Bandura [23], teachers who feel efficacious about teaching a particular curriculum (e.g. health-related curriculum) will be more likely to do so, compared to teachers who are less efficacious. Efficacious teachers employ effective problem solving skills, develop strategies to be more effective teachers, manage their emotions well, and persist in the face of failure. In short, self-efficacy is an all-encompassing concept that should be carefully analyzed and measured.

In the discipline of social psychology, several psychological measurement tools and instruments have been applied to measure teachers' self-efficacy including those used in the Teacher Efficacy Scale [12], the Teacher Sense of Efficacy Scale [4], and the Teacher Self-Efficacy Scale [24]. Although very useful in terms of general research, the measurement tools of teacher efficacy can be misleading in subjects that are specific. "A characteristic of many measurement instruments of teacher efficacy, including the Teacher Efficacy Scale, is the ability to assess teachers' ability beliefs about their functioning in general rather than teachers' beliefs in their ability to perform specific tasks. This is problematic considering that self- efficacy theory posits that self-efficacy beliefs are quite likely to differ among specific domains of activities" [23]. In order to overcome this conceptual and spatial hindrance, researchers have developed various scales for different teaching areas and special fields [25, 26].

When the literature is surveyed it is not surprising to find out that many studies $[27,28]$ have been conducted on the subject of physical education teachers' self-efficacy. A common shortcoming, however, is striking as in most of these studies general teacher efficacy scales have been used in the measurement of physical education teachers' both general and subject-oriented self-efficacy beliefs. In these studies [29, 30], the application of self-efficacy scales specifically developed for the physical education teachers has been very limited. Yet, both in theory and practice, as there are important differences between physical education lessons and the other lessons, there are and should be many differences between physical education teachers and the other teachers in areas such as teaching methods and teaching environment.

The main responsibility of a physical education teacher is developing a course curriculum and executing the lessons according to this curriculum, which aims at helping students gain physical exercise habits [31]. Besides this, a physical education teacher has other responsibilities such as conducting intra-school and interschool sports activities, taking part in the preparations and organizations for the ceremonies and parades of national holidays and special days, and coaching and officiating for professional development [32]. In order to meet all these demands of the profession, a physical education teacher has to carry required mental, physical, social and emotional capacity adequate for professional competence. Taking all these points in regard, it is necessary to use efficacy scales specifically adapted to physical education teachers if a sound contribution to the research literature in this field is to be made. Therefore, the first purpose of this study was to examine the psychometric properties of Teacher Interpersonal Self-Efficacy Scale that was developed by Brouwers and Tomic [5] and adapted to Turkish by Çapri and Kan [33] for physical education teachers. The second purpose was to analyze teachers' interpersonal self-efficacy beliefs according to gender, years of experience and grade levels they taught.

\section{Material and methods}

This study utilized the survey method that is used most commonly in descriptive research models [34, 35]. In the survey method, samples consist of large groups, and each member of the group is asked about their opinions in order to find out their attitudes on a case, fact or a situation. Researchers try to describe the facts or situations as they are and in their respected conditions [36].

Participants:

This study included 360 voluntary participants from different regions of Turkey who worked as physical education teachers in the education institutions (public schools organized under the National Department of Education) at the time of data collection. The sample consisted of 80 female and 280 male teachers whose ages ranged between 23 and 55 and whose years of experience ranged between 1 and 34. The average age and year of experience of the participants were 35.29 years $(\mathrm{SD}=$ $6.65)$ and 10.67 years $(\mathrm{SD}=6.81)$ respectively.

\section{Procedure:}

In this study, the Turkish adaptation of Teacher Interpersonal Self-Efficacy Scale (TISES) developed by Çapri and Kan [33] was used as the data collection instrument. The TISES developed by Brouwers and Tomic [5] that was developed to determine teachers' interpersonal self-efficacy belief levels consisted of 24 items and 3 subscales. The distribution of items in Brouwers and Tomic's subscales were listed as follows: perceived self-efficacy belief in classroom management (CM-14 items), perceived self-efficacy in eliciting support from colleagues subscale (ESFC-5 items), and perceived self-efficacy in eliciting support from principals subscale (ESFP-5 items). The Turkish version of the scale consists of 18 items and 3 subscales. The subscales carry the same titles as the original in the Turkish version but first subscale consists of 8 items instead of 14 original items of the TISES. The subscales were listed as follows: CM (e.g., I can manage my class very well), ESFC (e.g., I can always find colleagues with whom I can talk about problems at work), and ESFP (e.g., I am confident that if necessary I can ask principals for advice). All items were measured and sorted using a five-point Likert scale $(1=$ completely disagree, $2=$ disagree, $3=$ undecided, $4=$ agree, $5=$ completely agree) .

The data used in the study were collected online. The 
hyperlink of the website that included the questionnaire was sent to the participants and websites of various social media platforms formed by physical education teachers via electronic mail with detailed information on the purpose of the study and the directions to fill out the questionnaire.

Statistical Analysis:

Before the data analysis, all of the questionnaire forms were checked and a number of them were omitted from the analysis as they were incorrectly filled out. The sample size was adequate for factor analysis as the sample size used in this study was above $300[37,38]$. We calculated the descriptive statistics (mean, standard deviation, range, skewness and kurtosis) of the variables of the study with the intention of verifying to check if our data fell within the normalcy of the statistics that allows us to carry out the confirmatory factor analysis (CFA) or not. Kline [39] indicates that value of 3 for skewness and 10 for kurtosis is acceptable. We used the statistic program SPSS 20 for these calculations. CFA was employed to examine the construct validity using the maximum likelihood method with the program AMOS 18. To asses model fit, we used well-established indices such as chi-square/ degree of freedom $\left(\chi^{2} / \mathrm{df}\right)$, root mean square error of approximation (RMSEA), root mean residual (RMR), standardized root mean residual (SRMR), comparative fit index (CFI), Tucker-Lewis index (TLI), incremental fit index (IFI), goodness of fit index (GFI), and normed fit index (NFI). For the $\chi^{2} / \mathrm{df}$ values of less than 3 are considered adequate [39]. RMSEA and SRMR should be less than $0.08[40,41]$, whereas the RMR should be less than 0.05 [41, 42]. For the CFI, TLI, IFI, GFI, and NFI indices, values greater than 0.90 are considered acceptable and values greater than 0.95 indicate good fit to the data [41]. The cutoff value for factor loadings was 0.40 . Kline [43] suggested that loading values equal to or greater than 0.60 as high loading values, whereas loadings under 0.40 were low [44]. In order to provide evidence for validity, Pearson's product-moment coefficients were used in order to assess the correlations between the factors. Büyüköztürk [45], defined the situation in which the correlation coefficients ranged between 0.70 and 1.00 as high correlation. In same respect, when the correlation coefficients showed values between 0.30 and 0.70 it can be seen as average correlation, and low correlation occurs when the correlation coefficients are calculated between 0.00 and 0.30 . Cronbach's alphas were calculated for the subscales and total scale in order to evaluate their internal consistency [46]. Büyüköztürk [45] states that when Cronbach Alpha reliability coefficients are equal to or above 0.70 , it is a sufficient condition for the reliability of a scale in general. Multivariate analysis of variance (MANOVA) was used to determine differences between the scores acquired from the scale and the independent variables. Before the MANOVA, we also calculated skewness and kurtosis values and examined Box's M and Levene's statistics for all dependent variables in order to determine if the data provided the assumptions of the multivariate statistics.

\section{Results}

Confirmatory factor analysis (CFA) was conducted to test the factorial validity of the TISES. Before performing the CFA, we assessed the suitability of the data for factor analysis. Table 1 contains the means, standard deviations, skewness, kurtosis, and ranges for the total TISES and the three subscales. The skewness and kurtosis values showed that the data was distributed within the area of normalcy for confirmatory factor analysis.

The results of the CFA indicated that all fit indices except from the NFI reached acceptable levels as follows: $\chi^{2} / \mathrm{df}=2.48, \mathrm{GFI}=0.91, \mathrm{NFI}=0.88, \mathrm{CFI}=0.93, \mathrm{IFI}=0.93$, $\mathrm{TLI}=0.91, \mathrm{RMR}=0.03, \mathrm{SRMR}=0.05$, RMSEA $=0.06$. To define the contribution of each of the items with their respective factors, we also analyzed the standardized regression loadings and squared multiple correlations. In Table 2, all items, except for two items, demonstrated acceptable standardized regression loadings and squared multiple correlations. The item with the highest regression loadings (0.82) is number 18 (I can get through to most difficult students) which is related to the CM factor. The items with the lowest regression loadings are number 6 (There are very few students that I cannot handle) related to the CM factor and number 2 (When necessary, I am able to bring up problems with principals) related to the ESFP factor. These items did not fit the structure of the scale. Therefore, these items were omitted from the scale and item number was reduced to 16 . The results of the CFA of the 16 remaining items demonstrated an acceptable fit of the hypothetical factor model of the TISES $\left(\chi^{2} / \mathrm{df}=2.44\right.$, $\mathrm{GFI}=0.92, \mathrm{NFI}=0.91, \mathrm{CFI}=0.95, \mathrm{IFI}=0.95, \mathrm{TLI}=0.93$, $\mathrm{RMR}=0.03, \mathrm{SRMR}=0.05, \mathrm{RMSEA}=0.06$ ) with a threefactor structure.

After the CFA, our results confirmed the first factor (CM) as consisting of seven items whereas second (ESFC) and third (ESFP) factors yielded five and four items, respectively. Factor loading values of the items that belonged to the first factor ranged between 0.61 and 0.82 . Same values differed between 0.55 and 0.75 for the items in the second factor, and between 0.68 and 0.78 for those

Table 1. Descriptive statistics for the TISES

\begin{tabular}{|c|c|c|c|c|c|}
\hline Factor & M & SD & Skewness & Kurtosis & Range \\
\hline Classroom Management (CM) & 4.22 & 0.50 & -0.83 & 2.69 & $1.50-5.00$ \\
\hline Eliciting Support from Colleagues (ESFC) & 4.46 & 0.49 & -0.99 & 1.24 & $2.20-5.00$ \\
\hline Eliciting Support from Principals (ESFP) & 4.20 & 0.65 & -1.07 & 1.71 & $1.20-5.00$ \\
\hline Total & 4.28 & 0.44 & -0.69 & 0.80 & $2.61-5.00$ \\
\hline
\end{tabular}


Table 2. Statistical characteristic of items used in the CFA for the TISES

\begin{tabular}{|c|c|c|c|c|c|c|}
\hline Factor & $\begin{array}{l}\text { Item } \\
\text { Number }\end{array}$ & Item & M & SD & SRW & SMC \\
\hline \multirow[t]{8}{*}{$\mathrm{CM}$} & 1 & I can keep defiant students involved in my lessons. & 4.23 & 0.68 & 0.61 & 0.38 \\
\hline & 3 & I am able to respond adequately to defiant students. & 4.29 & 0.70 & 0.71 & 0.51 \\
\hline & 5 & I can manage my class very well. & 4.41 & 0.62 & 0.62 & 0.38 \\
\hline & 6 & There are very few students that I cannot handle. & 3.96 & 1.26 & 0.03 & 0.00 \\
\hline & 10 & I can keep a few problem students from ruining an entire class. & 4.28 & 0.69 & 0.71 & 0.51 \\
\hline & 14 & If students stop working, I can put them back on track. & 4.29 & 0.67 & 0.75 & 0.56 \\
\hline & 16 & $\begin{array}{l}\text { If a student disrupts the lesson, I am able to redirect him } \\
\text { quickly. }\end{array}$ & 4.18 & 0.71 & 0.78 & 0.61 \\
\hline & 18 & I can get through to most difficult students. & 4.08 & 0.81 & 0.82 & 0.67 \\
\hline \multirow[t]{5}{*}{ ESFC } & 4 & $\begin{array}{l}\text { I am able to approach my colleagues if I want to talk about } \\
\text { problems at work. }\end{array}$ & 4.48 & 0.69 & 0.59 & 0.35 \\
\hline & 7 & When it is necessary, I am able to ask a colleague for assistance. & 4.58 & 0.56 & 0.67 & 0.45 \\
\hline & 9 & $\begin{array}{l}\text { I can always find colleagues with whom I can talk about } \\
\text { problems at work. }\end{array}$ & 4.31 & 0.81 & 0.55 & 0.30 \\
\hline & 12 & $\begin{array}{l}\text { If I feel confronted by a problem with which my colleagues can } \\
\text { help me, I am able to approach them about this. }\end{array}$ & 4.46 & 0.65 & 0.75 & 0.56 \\
\hline & 15 & $\begin{array}{l}\text { I am confident that, if necessary, I can ask my colleagues for } \\
\text { advice. }\end{array}$ & 4.46 & 0.63 & 0.75 & 0.56 \\
\hline \multirow[t]{5}{*}{ ESFP } & 2 & When necessary, I am able to bring up problems with principals. & 4.18 & 0.93 & 0.37 & 0.14 \\
\hline & 8 & I am confident that if necessary I can ask principals for advice. & 4.27 & 0.83 & 0.68 & 0.47 \\
\hline & 11 & When it is necessary, I am able to get principals to support me. & 4.18 & 0.87 & 0.73 & 0.53 \\
\hline & 13 & $\begin{array}{l}\text { I am able to approach principals if I want to talk about problems } \\
\text { at work. }\end{array}$ & 4.25 & 0.87 & 0.76 & 0.58 \\
\hline & 17 & I am confident that, if necessary, I can get principals to help me. & 4.11 & 0.90 & 0.78 & 0.61 \\
\hline
\end{tabular}

Note: $\mathrm{M}=$ mean; $\mathrm{SD}=$ standard deviation; SRW = standardized regression weight; SMC = squared multiple correlation.

in the third factor. The latent variable of the $\mathrm{CM}$ factor explained between 0.38 and 0.67 of the variance, whereas the latent variable of the ESFC factor explained between 0.30 and 0.56 of the variance and the latent variable of the ESFP factor explained between 0.47 and 0.61 of the variance.

The correlations between each of the factors and Cronbach Alpha reliability coefficients for the subscales and total scale are depicted in Table 3. The correlation coefficients ranged between 0.49 and 0.89 . Cronbach Alpha values were calculated as $0.88,0.78,0.83$ and 0.90 for the subscales and total scale respectively.

Overall, all physical education teachers had positive self-efficacy beliefs on high levels as shown in Table 4 $(\mathrm{M}=4.30, \mathrm{SD}=0.48)$. When the three components of the TISES were examined, the values were $4.25(\mathrm{SD}=0.53)$ for $\mathrm{CM}$ factor, $4.46(\mathrm{SD}=0.49)$ for $\mathrm{ESFC}$ factor and 4.20 $(\mathrm{SD}=0.70)$ for ESFP factor respectively (Table 4).

A multi-variate analysis of variance (MANOVA) was conducted to examine the effects of gender, years of experience and grade levels on teacher interpersonal self- efficacy beliefs. Table 4 shows the means and standard deviations for the subscales and the total scale by gender, years of experience and grade levels. Results from the MANOVA indicated that there was no significant main effect of gender [Wilks' Lambda $=0.97, \mathrm{~F}(3,356)=0.51$, $\mathrm{p}=0.675]$ for any of the subscales. There was a significant main effect of years of experience [Wilks' Lambda $=0.97$, $\left.\mathrm{F}(3,356)=4.27, \mathrm{p}=0.006, \eta^{2}=0.035\right]$. In tests between subject effects by years of experience, results showed a significant difference in the Classroom Management $(\mathrm{CM})$ factor $\left[\mathrm{F}(1,358)=9.20, \mathrm{p}=0.003, \eta^{2}=0.025\right]$. The experienced teachers had higher self-efficacy scores $(\mathrm{M}=4.35, \mathrm{SD}=0.51)$. Whereas by grade levels a significant main effect was not found [Wilks' Lambda $=0.98, \mathrm{~F}(3$, $356)=2.16, p=0.093$ ], a significant difference was found between teachers depending on grade levels they taught in the Classroom Management $(\mathrm{CM})$ factor $[\mathrm{F}(1,358)=5.95$, $\left.p=0.015, \eta^{2}=0.016\right]$. The teachers who were employed at the high schools had higher self-efficacy scores $(\mathrm{M}=4.33$, $\mathrm{SD}=0.46$ ) than the teachers who were employed at the middle schools $(\mathrm{M}=4.19, \mathrm{SD}=0.58)$. 
Table 3. Correlations among the TISES revised

\begin{tabular}{llllll}
\hline Factor & CM & ESFC & ESFP & Total & Alpha \\
\hline Classroom Management (CM) & 1.00 & & & & 0.88 \\
Eliciting Support from Colleagues (ESFC) & $0.50^{*}$ & 1.00 & & & 0.78 \\
Eliciting Support from Principals (ESFP) & $0.49^{*}$ & $0.65^{*}$ & 1.00 & & 0.83 \\
Total & $0.78^{*}$ & $0.84^{*}$ & $0.89^{*}$ & 1.00 & 0.90 \\
\hline
\end{tabular}

${ }^{*} p<0.01$

Table 4. Descriptive statistics for the TISES revised

\begin{tabular}{|c|c|c|c|c|c|c|c|c|c|c|c|c|c|c|}
\hline \multirow[t]{2}{*}{ Factor } & \multicolumn{2}{|c|}{$\begin{array}{l}\text { Total } \\
(n=360)\end{array}$} & \multicolumn{2}{|c|}{$\begin{array}{l}\text { Female } \\
(n=80)\end{array}$} & \multicolumn{2}{|c|}{$\begin{array}{l}\text { Male } \\
(n=280)\end{array}$} & \multicolumn{2}{|c|}{$\begin{array}{l}\mathbf{0 - 1 0} \text { years } \\
(n=198)\end{array}$} & \multicolumn{2}{|c|}{$\begin{array}{l}\text { 11-34 years } \\
(n=162)\end{array}$} & \multicolumn{2}{|c|}{$\begin{array}{l}\text { Middle School } \\
(n=194)\end{array}$} & \multicolumn{2}{|c|}{$\begin{array}{l}\text { High School } \\
(n=166)\end{array}$} \\
\hline & $M$ & SD & M & SD & M & SD & M & SD & M & SD & $\mathbf{M}$ & SD & M & SD \\
\hline CM & 4.25 & 0.53 & 4.25 & 0.45 & 4.26 & 0.55 & 4.18 & 0.51 & 4.35 & 0.55 & 4.19 & 0.58 & 4.33 & 0.46 \\
\hline ESFC & 4.46 & 0.49 & 4.51 & 0.41 & 4.44 & 0.52 & 4.46 & 0.49 & 4.46 & 0.50 & 4.42 & 0.51 & 4.49 & 0.48 \\
\hline ESFP & 4.20 & 0.70 & 4.24 & 0.63 & 4.19 & 0.72 & 4.20 & 0.72 & 4.20 & 0.68 & 4.14 & 0.74 & 4.27 & 0.66 \\
\hline Total & 4.30 & 0.48 & 4.33 & 0.40 & 4.30 & 0.50 & 4.28 & 0.49 & 4.34 & 0.48 & 4.25 & 0.51 & 4.36 & 0.44 \\
\hline
\end{tabular}

$(\mathrm{CM}=$ Classroom Management; ESFC=Eliciting Support from Colleagues; ESFP=Eliciting Support from Principals)

\section{Discussion}

This study was conducted to adapt the TISES, which was originally developed in order to measure interpersonal self-efficacy belief levels of the teachers, to PE teachers and analyze the PE teachers' interpersonal self-efficacy beliefs according to gender, years of experience and grade levels they taught. To ascertain the factor structure of this scale, CFA was administered. The results of the CFA for 16 items showed relative improvement in some fit indices that had low values in 18 items such as NFI (0.88). Factor loadings of the items that belonged to the subfactors, ranged between 0.55 and 0.82. Same values differed between 0.59 and 0.81 in Çapri and Kan's (2006) [33] study, and between 0.36 and 0.96 in Garcia-Ros, Fuentes and Fernandez's [47] study and between 0.52 and 0.90 in Moura and Costa's [48] study and between 0.45 and 0.90 in Brouwers and Tomic's [5] study. The results of the correlation analysis showed that the subscales were moderately related to each other, and all were highly correlated with the total TISES score. In our study, the correlation coefficients among the subfactors were calculated between 0.49 and 0.65 . These values are in parallel with the results of Çapri and Kan's [33] and Garcia-Ros, Fuentes and Fernandez's [47] and Moura and Costa's [48] studies that arrived at correlation values between $0.45-0.54$ and $0.50-0.56$ and $0.49-0.54$ respectively. In Brouwers and Tomic's [5] study, the correlations coefficients were calculated between 0.32 and 0.57 . The analyses that were made to determine the reliability level of the scale indicated that the scale had a high reliability level. Cronbach Alpha values for the subscales were calculated between 0.78 and 0.83 in this study. These values ranged between 0.89 and 0.91 in Çapri and Kan's [33] study, and between 0.92 and 0.94 in Garcia-Ros, Fuentes and Fernandez's [47] study and between 0.91 and 0.93 in Moura and Costa's [48] study. Brouwers and Tomic [5] reported that the reliability coefficients for the TISES subscales were above 0.90 in their study.

Overall, descriptive statistics showed that the PE teachers' scores from total TISES and its subscales were on fairly high levels. In other words, the participants had positive interpersonal self-efficacy beliefs. These findings were consistent with the results of some studies which were made in Turkey [49, 50]. In contrast with these results, it was reported that the teachers had moderately self-efficacy beliefs in some studies which were made abroad $[5,51]$. However, the reason for this disparity may be related to culture. The results of some studies in the literature revealed that the culture, where the teachers lived in, affected their teacher self-efficacy beliefs [52, 53].

In regards to the influence of gender on self-efficacy levels, our study found that there was no significant difference between the self-efficacy levels of male and female PE teachers. Similar findings were reported in some studies which were conducted on teachers and pre-service teachers $[54,55]$. Mouton et al also found no significant difference by gender in their study, which was conducted on $119 \mathrm{PE}$ teachers in order to determine the relationship between emotional intelligence and selfefficacy [56].

The results of our study revealed that the experienced PE teachers had higher self-efficacy belief levels. The results supported the findings of other studies [57, 58]. Mouton et al, however, found no significant relationships between ages, years of physical education teaching and self-efficacy beliefs of the teachers [56]. The reason for this difference may be related to sample characteristics. Whereas the mean age and years of teaching experience 
of the participants in this study were 35.29 and 10.67 respectively, the same values in Mouton et al's [56] study were 42.1 and 18.2. The literature confirms that self-efficacy belief increases by time and experience [9]. Bandura [23, 59] expressed the view that the formation of a person's self-efficacy belief could only be realized with that person going through the direct life experiences, which constituted one of the most important informative sources of Bandura's related theory. Moreover, Bandura [10] argued that experiences were one of the most important factors that affected the self-efficacy beliefs and that the positive experiences contributed to the development of self-efficacy belief.

According to the findings of our study, on the classroom management subdimension the TISES scores of the participants pointed to significant difference based on the grade levels the PE teachers taught at. In other sub-dimensions, however, although the mean scores of the teachers taught at the high school level are high, it did not point to a significant difference. In respect to the classroom management subdimension, the PE teachers who were employed at the high schools had higher selfefficacy scores than the PE teachers who were employed at the middle schools. The studies that subjected the effect of this variable on self-efficacy are pretty limited in the literature. Among these studies, the study conducted by Akkoyunlu and Kurbanoğlu [60] and Özgün [61] obtained similar findings that our study arrived at. In an effort to interpret the above mentioned phenomenon, the effect of ages and experience levels of the middle school and high school PE teacher on self-efficacy were analysed. We found that the average year of experience for the high school PE teachers was 12.27, whereas the same score was 9.30 for the middle school PE teachers. Based on these findings and in tandem with the results about experience mentioned above, it can be stated that such a result might be affected by years spent on teaching.

\section{Conclusions}

In this study, the validity and reliability of the Teacher Interpersonal Self-Efficacy Scale was tested for PE teachers. The reexamination of the scale led to a new scale structure comprised of three factors with sixteen items. The results obtained after validity and reliability analyses confirmed that the restructured scale can be applied on the PE teachers. The distribution of items in the subscales were listed as follows: perceived self-efficacy belief in classroom management (CM-7 items), perceived selfefficacy in eliciting support from colleagues subscale (ESFC-5 items), and perceived self-efficacy in eliciting support from principals subscale (ESFP-4 items). The scale includes a brief questionnaire that is easy to apply and evaluate. Overall, all PE teachers had positive selfefficacy beliefs on high levels. Whereas a significant difference was not found in self-efficacy beliefs by gender, significant differences were found between teachers depending on their experience and grade levels they taught. The experienced teachers had higher selfefficacy belief levels. Additionally, the teachers who were employed at the high schools had higher self-efficacy beliefs than the teachers who were employed at the middle schools. While this study had its limitations in terms of its sample characteristics and target sample, this can be overcome with the administration of the scale on different and larger samples. Future studies that will use different and larger samples can further contribute to the validity and reliability of the scale. Further studies should also include qualitative tools such as interviews, which may help provide further understanding about the issue.

\section{Conflicts of Interest}

The authors declare no conflict of interest.

\section{References}

1. Martin JJ, Mccaughtry N, Kulinna PH, Cothran D. The influences of professional development on teachers' self-efficacy toward educational change. Physical Education and Sport Pedagogy, 2008; 13(2): 171-190. https://doi.org/10.1080/17408980701345683

2. Bergman P, McLaughlin M, Bass M, Pauly E, Zellman G. Federal programs supporting educational change: Vol. VII. Factors affecting implementation and continuation. Santa Monica, CA: RAND; 1977.

3. Guskey TR, Passaro PD. Teacher efficacy: A study of construct dimensions. American Educational Research Journal, 1994; 31(3): 627-643. https://doi.org/10.3102/00028312031003627

4. Tschannen-Moran M, Hoy AW. Teacher efficacy: Capturing an elusive construct. Teaching and Teacher Education, 2001; 17(7): 783-805. https://doi.org/10.1016/S0742-051X(01)00036-1

5. Brouwers A, Tomic W. The factorial validity of scores on the teacher interpersonal self-efficacy scale. Educational and Psychological Measurement, 2001; 61(3): 433-445. https://doi.org/10.1177/00131640121971301

6. Caprara GV, Barbaranelli C, Steca P, Malone PS. Teacher self-efficacy beliefs as determinants of job satisfaction and students' academic achievement: A study at the school level. Journal of School Psychology, 2006; 44: 473-490. https://doi.org/10.1016/j.jsp.2006.09.001

7. Brouwers A, Tomic W. A longitudinal study of teacher burnout and perceived self-efficacy in classroom management. Teaching and Teacher Education, 2000; 16: 239-253. https://doi.org/10.1016/S0742-051X(99)00057-8

8. Ashton PT, Webb RB. Making a difference: Teachers sense of efficacy and student achievement. White Plains, NY: Longman; 1986.

9. BanduraA.Self-efficacy:Towardaunifyingtheoryofbehavioral change. Psychological Review, 1977; 84(2): 191-215. http://dx.doi.org/10.1037/0033-295X.84.2.191

10.Bandura A. Social foundations of thought and action: A social cognitive theory. Englewood Cliffs, NJ: Prentice Hall; 1986.

11.Ross JA. Teacher efficacy and the effect of coaching on student achievement. Canadian Journal of Education, 1992;17:51-65. https://www.jstor.org/stable/1495395

12.GibsonS,DemboMH.Teacherefficacy :Aconstructvalidation. Journal of Educational Psychology, 1984; 76(4): 569-582. http://dx.doi.org/10.1037/0022-0663.76.4.569 
13.Tschannen-Moran M, Woolfolk Hoy A, Hoy WK. Teacher efficacy: Its meaning and measure. Review of Educational Research, 1998; 68: 202-248. https://doi.org/10.3102/00346543068002202

14.Coladarci T. Teachers' sense of efficacy and commitment to teaching. Journal of Experimental Education, 1992; 60: 323-337. https://doi.org/10.1080/00220973.1992.9943869

15.Caprara GV, Barbaranelli C, Borgogni L, Steca P. Efficacy beliefs as determinants of teachers' job satisfaction. Journal of Educational Psychology, 2003; 95(4): 821-832. http://dx.doi.org/10.1037/0022-0663.95.4.821

16.Tschannen-Moran M, Hoy AW. The differential antecedents of self-efficacy beliefs of novice and experienced teachers. Teaching and Teacher Education, 2007; 23(6): 944-956. https://doi.org/10.1016/j.tate.2006.05.003

17.Klassen RM, Bong M, Usher EL, Chong WH, Huan VS, Wong IYF, et al. Exploring the validity of a teachers' self-efficacy scale in five countries. Contemporary Educational Psychology, 2009; 34: 67-76. https://doi.org/10.1016/j.cedpsych.2008.08.001

18.Hoover-Dempsey KV, Bassler OC, Brissie JS. Parent involvement: Contributions of teacher efficacy, school socioeconomic status, and other school characteristics. American Educational Research Journal, 1987; 24: 417-435. https://doi.org/10.3102/00028312024003417

19.Chester MD, Beaudin BQ. Efficacy beliefs of newly hired teachers in urban schools. American Educational Research Journal, 1996; 33: 233-257. https://doi.org/10.3102/00028312033001233

20.Hoy WK, Woolfolk AE. Teachers' sense of efficacy and the organizational health of schools. The Elementary School Journal, 1993; 93: 355-372. https://doi.org/10.1086/461729

21.Timperley HS, Phillips G. Changing and sustaining teachers' expectations through professional development in literacy. Teaching and Teacher Education, 2003; 19: 627-641. https://doi.org/10.1016/S0742-051X(03)00058-1

22.Oreck B. The artistic and professional development of teachers. Journal of Teacher Education, 2004; 55: 55-69.

23.Bandura A. Self-efficacy: The exercise of control. New York, NY: Freeman; 1997.

24.Bandura A. Multi-dimensional scales of perceived academic efficacy. Stanford, CA: Stanford University Press; 1990.

25.Enochs L, Riggs IM. Further development of an elementary science teaching efficacy belief instrument: A preservice elementary scale. School Science and Mathematics, 1990; 90(8): 694-706. https://doi.org/10.1111/j.1949-8594.1990.tb12048.x

26.Goddard RD, Hoy WK, Hoy AW. Collective teacher efficacy: Its meaning, measure, and impact on student achievement. AmericanEducationalResearchJournal,2000;37(2):479-507. https://doi.org/10.3102/00028312037002479

27.Öksüzoğlu P. Self perceptions of on proficiency in teaching profession physical education teacher candidates. Unpublished master thesis, Mersin University, Mersin; 2009.

28. Yılmaz G, Yılmaz B, Türk N. Over-graduate thesis physical education and sports teacher's self-efficacy of their jobs (Nevşehir city model). Selçuk University Journal of Physical Education and Sport Science, 2010; 12(2): 85-90.

29.Martin JJ, Kulinna PH. The development of a physical education teachers' physical activity self-efficacy instrument. Journal of Teaching in Physical Education, 2003; 22:219-232. https://doi.org/10.1123/jtpe.22.2.219

30.Ünlü H, Sünbül AM, Aydos L. The study of physical education teachers' self-efficacy scale of validity and reliability. Ahi Evran University Journal of Kırşehir Education Faculty, 2008; 9(2): 23-33.

31.Darst PW, Pangrazi RP. Dynamic physical education for secondary school students (6th ed.). San Francisco, CA: Pearson Education; 2009.

32.Tamer K, Pulur A. Beden eğitimi ve sporda öğretim yöntemleri [Teaching methods in physical education and sports]. Ankara: Kozan Ofset Yayınc1lık; 2001 (In Turkish).

33.Çapri B, Kan A. The teacher interpersonal self-efficacy scale: Validity and reliability study of Turkish form. Mersin University Journal of the Faculty of Education, 2006; 2(1): 48-61.

34.Jones I, Gratton C. Research methods for sports studies. London: Routledge; 2004.

35.Thomas JR, Nelson JK. Research methods in physical activity (3rd ed.). Champaing, IL: Human Kinetics; 1996.

36.Karasar N. Bilimsel araştırma yöntemi (14.Basım) [Scientific research method (14th ed.)]. Ankara: Nobel Yayın ve Dağııtım; 2005 (in Turkish).

37.Comrey AL, Lee HB. A first course in factor analysis. Hillsdale, NJ: Erlbaum; 1992.

38.Cureton EE, D'Agostino RB. Factor analysis: An applied approach. Hillsdale, NJ: Erlbaum; 1983.

39.Kline RB. Principles and practice of structural equation modeling: Methodology in the social sciences. New York, NY: Guilford Press; 2005.

40.Jöreskog KG, Sörbom D. Lisrel 8: Structural equation modeling with the simplis command language. Lincolnwood, IL: Scientific Software International; 1993.

41.Hu L, Bentler PM. Cutoff criteria for fit indexes in covariance structure analysis: Conventional criteria versus new alternatives. Structural Equation Modeling, 1999; 6: 1-55. https://doi.org/10.1080/10705519909540118

42.Brown TA. Confirmatory factor analysis for applied research. New York, NY: Guilford Publications; 2006.

43.Kline P. An easy guide to factor analysis. New York, NY: Routledge; 1994.

44.Hair JF, Black WC, Babin BJ, Anderson RE, Tatham RL. Factor analysis (Chapter 3). In multivariate data analysis with readings (5th ed.). Englewood Cliffs, NJ: Prentice Hall; 2006.

45.Büyüköztürk Ş. Sosyal bilimler için veri analizi el kitabı (9.Basım) [Data analysis handbook for social sciences (9th ed.)]. Ankara: Pegem Akademi; 2008 (in Turkish).

46.Cronbach LJ. Coefficient alpha and internal structure of tests. Pyschometrica, 1951; 16: 297-334.

47.Garcia-Ros R, Fuentes MC, Fernandez B. Teachers' interpersonal self-efficacy: Evaluation and predictive capacity of teacher burnout. Electronic Journal of Research in Educational Psychology, 2015; 13(3): 483-502. http:// dx.doi.org/10.14204/ejrep.37.14105

48. Moura O, Costa C. Teacher Interpersonal Self-Efficacy Scale: Estudo de adaptação e validação da versão Portuguesa [In the adaptation and validation of the Portuguese version]. Análise Psicológica, 2016; 1(34): 87-99 (in Portuguese). https://doi.org/10.14417/ap.1070

49.Çapri B, Kan A. The investigation of the teachers' interpersonal self-efficacy beliefs according to working experiences, type of school worked in, educational level worked in, and professional position. Mersin University Journal of the Faculty of Education, 2007; 3(1): 63-83.

50.Saracaloğlu AS, Aydoğdu B. An investigation of science teachers' interpersonal self-efficacy beliefs in terms of some variables. International Journal of New Trends in Arts, Sports 
\& Science Education, 2012; 1(1): 21-35.

51.Hoy AW, Spero RB. Changes in teacher efficacy during the early years of teaching: A comparison of four measures. Teaching and Teacher Education, 2005; 21(4): 343-356. https://doi.org/10.1016/j.tate.2005.01.007

52.Çakıroğlu E. The teaching efficacy beliefs of preservice teachers in the USA and Turkey. Journal of Education for Teaching, 2008; 34(1): 33-44. https://doi.org/10.1080/02607470701773457

53.Lin H, Gorrell J, Taylor J. Influence of culture and education on U.S. and Taiwan preservice teachers' efficacy beliefs. The Journal of Educational Research, 2002; 96(1): 37-46. https://doi.org/10.1080/00220670209598789

54.Sandıkçı M, Öncü E. Determination and comparison of physical education and the other pre-service teachers' selfefficacy beliefs and attitudes toward teaching profession. Pamukkale Journal of Sport Sciences, 2013; 4(1): 135-151.

55.Topkaya EZ, Yavuz A. Democratic values and teacher self-efficacy perceptions: A case of pre-service English language teachers in Turkey. Australian Journal of Teacher Education, 2011; 36(8): 32-49. http://dx.doi.org/10.14221/ajte.2011v36n8.1
56. Mouton A, Hansenne M, Delcour R, Cloes M. Emotional intelligence and self-efficacy among physical education teachers. Journal of Teaching in Physical Education, 2013; 32: 342-354. https://doi.org/10.1123/jtpe.32.4.342

57.Dembo MH, Gibson S. Teachers' sense of efficacy: An important factor in school improvement. The Elemantary School Journal, 1985; 99: 3-10. https://doi.org/10.1086/461441

58. Soodak LC, Podell DM. Teacher efficacy and student problem as factors in special education referral. Teaching and Teacher Education, 1996; 12(4): 401-411. https://doi.org/10.1177/002246699302700105

59.Bandura A. Self-efficacy in changing societies. New York; NY: Cambridge University Press; 1995.

60.Akkoyunlu B, Kurbanoğlu S. A study on teachers' information literacy self-efficacy beliefs. Hacettepe University Journal of Education, 2004; 27: 11-20.

61.Özgün MS. A survey between the school psychological counselors personality features and occupational selfefficacy. Unpublished master dissertation, Cukurova University, Adana; 2007.

\section{Information about the author:}

Öncü E.; http://orcid.org/0000-0002-7932-5558; eoncu@ktu.edu.tr; Faculty of Sport Sciences, Department of Physical Education and Sport Teaching; 61300 Akcaabat-Trabzon, Turkey.

\section{Cite this article as:}

Öncü E. An examination of Turkish physical education teachers' interpersonal self-efficacy beliefs. Physical education of students, 2019;23(1):37-44.

https://doi.org/10.15561/20755279.2019.0106

The electronic version of this article is the complete one and can be found online at: https://sportedu.org.ua/index.php/PES/issue/archive

This is an Open Access article distributed under the terms of the Creative Commons Attribution License, which permits unrestricted use, distribution, and reproduction in any medium, provided the original work is properly cited http://creativecommons.org/licenses/by/4.0/deed.en

Received: 04.01.2019

Accepted: 05.02.2019; Published: 28.02.2019 